\title{
ANALISIS SPASIAL BESARAN TINGKAT EROSI PADA TIAP SATUAN LAHAN DI SUB DAS BATANG KANDIS
}

\author{
Rusnam $^{1}$, Eri Gas Ekaputra ${ }^{1}$,Erich Mansyur Sitanggang ${ }^{2}$, \\ ${ }^{1}$ Dosen Fakultas Teknologi Pertanian, Kampus Limau Manis-Padang 25163, \\ ${ }^{2}$ Alumni Fakultas Teknologi Pertanian, Kampus Limau Manis-Padang 25163 \\ Email: rusnam_ms@yahoo.com
}

ABSTRAK

\begin{abstract}
Penelitian ini dilakukan pada bulan Agustus dan September 2013 di Sub-DAS Batang Kandis di distrik Koto Tangah Kota Padang dan juga di AMGIS (Sistem Informasi Manajemen Pertanian Geographic) Laboratory. Penelitian ini bertujuan untuk menghitung laju erosi dan menentukan tingkat bahaya erosi dan mengatur arahan konservasi tanah dan konservasi tanah untolerated untuk pengendalian erosi. Metode yang digunakan dalam penelitian ini adalah USLE (Universal Soil Loss Equation) dengan pendekatan Sistem Informasi Geografis. Berdasarkan hasil penelitian ini menunjukkan bahwa dari seluruh areal sub-DAS Batang Kandis daerah, diketahui bahwa kriteria tingkat bahaya erosi sangat tinggi adalah areal terkecil dengan luas 53,292 hektar, sekitar 0,97 \% . Hal ini menunjukkan bahwa sebagian besar sub-DAS Batang Kandis memiliki nilai erosi yang masih bisa ditoleransi. Tingkat erosi terbesar di Sub-DAS Batang Kandis terjadi pada satuan lahan KCB sama dengan 1368.246 ton/ha/tahun. Dari hasil identifikasi berdasarkan arah rehabilitasi lahan dan konservasi tanah, maka diperoleh bahwa satuan lahan KCB dan KCL adalah prioritas utama sebagai daerah yang memerlukan tindakan konservasi .
\end{abstract}

Keyword: Erosi, USLE, Unit Tanah, Sistem Informasi Geografis, Rehabilitasi Lahan dan Konservasi Tanah

\section{ABSTRACT}

This study was conducted in August and September 2013 in the Sub-Watershed of Batang Kandis in the district Koto Tangah of Padang City and also in AMGIS (Agriculture Management Geographic Information System) Laboratory. This study was purposed to calculate the rate of erosion and determine the level of erosion hazard and arrange soil conservation referrals and the untolerated soil conservation for erosion control. The method used in this research is the USLE (Universal Soil Loss Equation) with Geographic Information System approach. Based on the results of this study showed that from the entire acreage of sub-watershed Batang Kandis area, it is known that the very high erosion hazard level criteria was the smallest acreage with an area of 53.292 hectares, approximately $0.97 \%$. This suggests that most of the sub-watershed Batang Kandis has erosion value that can still be tolerated. The greatest erosion rates in Sub-watershed Batang Kandis occur at KCB land units is equal to 1368.246 tonnes/ha/year. From the results of identification based on direction of land rehabilitation and soil conservation, then obtained that the land units KCB and $K C L$ was the major priority as the areas which is need the conservation action.

Keyword: Erosion, USLE, Land Unit, Geographic Information System, Land Rehabilitation and Soil Conservati 


\section{Pendahuluan}

Peningkatan jumlah penduduk diikuti dengan aktivitas pembangunan yang semakin cepat mengakibatkan melonjaknya kebutuhan manusia terutama kebutuhan pokoknya terhadap sumber daya lahan. Dalam memenuhi kebutuhan manusia akan sumber daya lahan tersebut dilakukan dengan cara suatu bentuk pemanfaatan lahan. Kerusakan DAS sering dipicu oleh perubahan tata guna lahan yang disebabkan oleh aktivitas manusia dalam pemanfaatan lahan dibagian hulu DAS yang tidak memperhatikan konservasi dapat mengakibatkan erosi. Dimana erosi yang terjadi akan mengakibatkan penurunan produktivitas lahan yang pada akhirnya menimbulkan terjadinya degradasi lahan. Selama proses erosi sebagian besar air akan menghilang dalam bentuk aliran permukaan yang cepat akibat penurunan laju infiltrasi air kedalam tanah dan penurunan kemampuan tanah menahan air. Peningkatan laju erosi dapat mengakibatkan fungsi hidrologis dari DAS tersebut tidak berjalan dengan baik seperti terjadinya fluktuasi debit aliran permukaan yang tinggi dan sedimentasi.

Salah satu wilayah yang menjadi perhatian adalah Sub DAS Batang Kandis, yang mana bagian muara Sub DAS menyatu dengan muara masing-masing sungai yaitu Batang Anai dan Batang Kasang. Sub DAS Batang Kandis terletak di Kecamatan Koto Tangah Kota Padang yang memiliki luas areal 5506,56 Ha. Dilihat dari jenis penggunaan lahan yang paling mendominasi pada Sub DAS Batang Kandis yaitu hutan dan kebun campuran. Sebagian areal pada jenis penggunaan lahan kebun campuran tersebut memiliki kemiringan lereng yang curam. Hal ini dapat memberikan pengaruh kemungkinan terjadinya erosi pada penggunaan lahan yang tidak sesuai dengan tingkat kelerengan tersebut. Bagian hilir Sub DAS Batang Kandis merupakan daerah rawan banjir dan menjadi kekeringan di musim kemarau. Dalam hal ini menandakan bahwa ada kemungkinan kawasan Sub DAS telah mengalami banyak perubahan akibat pemanfaatan lahan yang kurang sesuai dengan fungsinya yang disebabkan peningkatan jumlah penduduk di daerah Sub DAS Batang Kandis. Berdasarkan data BPS (Badan
Pusat Statistik) dalam angka tahun 2007, Kecamatan Koto Tangah ini berjumlah 157956 jiwa, sedangkan pada tahun 2011 jumlah penduduknya 166148 jiwa (BPS Kota Padang, 2012). Dari data jumlah penduduk di Kecamatan Koto Tangah menunjukkan terjadinya peningkatan penduduk sebanyak 8192 jiwa.

Apalagi seiring dengan dikeluarkannya Peraturan Pemerintah Nomor 26 Tahun 2011 pada tanggal 18 April 2011, pusat pemerintahan Kota Padang secara resmi dipindahkan dari Kecamatan Padang Barat ke Kecamatan Koto Tangah untuk mengurangi konsentrasi masyarakat di kawasan pantai dan mendekatkan pelayanan kepada masyarakat serta mempercepat pertumbuhan ekonomi dan pembangunan di Kota Padang. Dalam situasi yang seperti ini nantinya Sub DAS Batang Kandis kemungkinan akan mengakibatkan terjadinya pembukaan dan perluasan lahan baru seperti pemukiman, konversi hutan menjadi lahan perkebunan dan jaringan infrastruktur yang nantinya akan mendukung kegiatan perluasan kota. Oleh sebab itu, diperlukan metode prediksi erosi untuk mengetahui besarnya laju erosi yang terjadi.

Untuk memprediksi laju erosi biasanya digunakan metode empiris yang telah banyak dikembangkan seperti USLE dan SDR. Akan tetapi, dalam hal ini metode yang digunakan dalam penelitian ini yaitu dengan menggunakan metode USLE (Universal Soil Loss Equation) yang menjadikan beberapa parameter sebagai faktor yang mempengaruhi erosi yaitu erosivitas hujan, erodibilitas tanah, panjang dan kemiringan lereng, tata guna lahan dan pengolahan lahan. Dengan bantuan aplikasi Sistem Informasi Geografis (SIG) yang merupakan teknologi berbasis spasial yang mempunyai kemampuan untuk menghubungkan berbagai data ke dalam perhitungan prediksi erosi dengan metode USLE untuk dapat memberikan informasi daerah yang memiliki laju besaran erosi secara spasial dengan cepat dan akurat yaitu dengan menumpang susunkan atau overlay ke semua parameter yang mempengaruhi terjadinya laju besaran erosi. 
Berdasarkan permasalahan tersebut peneliti tertarik melakukan penelitian yang berjudul "Analisis Spasial Besaran Tingkat Erosi pada Tiap Satuan Lahan Di Sub DAS Batang Kandis".

Adapun tujuan dari penelitian adalah : untuk menghitung besar laju erosi dan menentukan tingkat bahaya erosi serta menyusun arahan rehabilitas lahan dan konservasi tanah yang tidak dapat ditoleransi untuk mengendalikan erosi.

\section{Metodologi}

Pelaksanaan penelitian ini dilakukan pada bulan Agustus sampai September 2013. Lokasi penelitian terletak di Sub DAS Batang Kandis di wilayah Kecamatan Koto Tangah Kota Padang. Secara geografis, letak Sub DAS Batang Kandis berada di $100^{\circ} 18 ' 50 " \mathrm{BT}-100^{\circ} 25^{\prime} 10^{\prime \prime} \mathrm{BT}$ dan $0^{\circ} 44^{\prime} 35^{\prime \prime} \mathrm{LS}$ $0^{\circ} 51^{\prime 20}$ " LS. Pengolahan dan analisis data dilakukan di Laboratorium Manajemen Pertanian dan Sistem Informasi Geografis Fakultas Teknologi Pertanian Universitas Andalas Padang.

\section{Bahan dan Alat}

Bahan - bahan yang diperlukan dalam penelitian ini adalah : Peta Jenis Tanah Sumatera Barat tahun 2011, Peta Penutup / Penggunaan Lahan Sumatera Barat tahun 2011, Peta Kemiringan Lereng Sumatera Barat tahun 2011 yang diperoleh dari BPDAS Agam Kuantan, Peta Topografi Jantop TNI AD 1986 lembar 0715-32 dan 0715-34 diperoleh dari Dinas PSDA Provinsi Sumatera Barat, Data curah hujan 10 tahun terakhir sesuai dengan stasiun pengamatan hujan yang diperoleh dari Dinas PSDA Provinsi Sumatera Barat. Alat alat yang diperlukan dalam penelitian ini adalah : perangkat Komputer dengan perangkat lunak yaitu ArcGIS 9.3 dan Microsoft Office untuk pengolahan hasil, GPS (Global Position System) untuk menentukan posisi lokasi penelitian, perlengkapan alat tulis, kamera digital digunakan untuk dokumentasi di lapangan, dan alat penunjang lainnya.

\section{Metode Penelitian}

Metode yang digunakan dalam penelitian ini adalah metode USLE (Universal Soil Loss Equation) yang merupakan metode yang memungkinkan dirancang untuk memprediksi laju rata - rata erosi dalam jangka waktu panjang dalam suatu bidang tanah tertentu dengan pendekatan Sistem Informasi Geografis yaitu metode untuk memprediksi laju erosi secara spasial yang diperoleh dari hasil overlay peta curah hujan, peta jenis tanah, peta kemiringan lereng dan peta penggunaan lahan dalam bentuk spasial melalui tahapan kerja yang terdiri dari pemasukan (input), proses (process), dan keluaran (output). Adapun tahapan dari metode yang digunakan dalam pelaksanaan penelitian ini antara lain : pengumpulan data, pengolahan dan analisis data disertai dengan penentuan tingkat bahaya erosi guna penyusunan rekomendasi arahan konservasi.

\section{Pengumpulan Data}

Pengumpulan data dilakukan untuk mendapatkan semua informasi penelitian yang berguna dalam menganalisis laju erosi dan tingkat bahaya erosi. Adapun data yang digunakan dalam penelitian ini dalam pendugaan erosi dengan metode USLE yaitu data peta dan data sekunder antara lain : peta jenis tanah, peta kemiringan lereng, peta penggunaan lahan yang diperoleh dari BPDAS Agam Kuantan. Peta Topografi Jantop TNI AD 1986 dan data curah hujan bulanan 10 tahun terakhir yang diperoleh dari Dinas PSDA Provinsi Sumatera Barat.

\section{Pengolahan dan Analisis Data}

Pengolahan dan analisis data dilakukan dengan menggunakan pendekatan Sistim Informasi Geografis (SIG) dengan perangkat lunak ArcGIS 9.3. Proses pengolahan dan analisis data dilakukan terhadap keempat jenis peta untuk memperoleh nilai faktor dari masing - masing parameter erosi yang diperlukan dalam penghitungan tingkat bahaya erosi. Keempat jenis peta tersebut, yaitu peta erosivitas hujan $\mathrm{R}$, peta erodibilitas tanah $\mathrm{K}$, peta kemiringan lereng LS dan peta penutupan / penggunaan lahan CP. Dari keempat jenis peta tersebut digunakan dalam analisis ini dengan interaksi antara metode USLE dan aplikasi SIG yang dapat memprediksi laju erosi secara spasial pada tiap satuan lahan. Peta laju erosi dapat diperoleh dengan tumpang-susun (overlay) keempat jenis peta dari parameter USLE tersebut 
pada tiap satuan lahan. Hasil akhir dari analisis SIG tersebut diperoleh satuan lahan dalam bentuk spasial dengan segala data atribut yang dihasilkan dari proses tumpang susun. Setiap satuan lahan yang diperoleh diberi nomor untuk mempermudah analisis lebih lanjut. Secara lebih rinci pengolahan dan analisis data dalam menentukan nilai faktorfaktor erosi diprediksi dengan memakai metode Universal Soil Loss Equation (USLE) yang dikemukakan oleh Wischmeier dan Smith 1978 (Arsyad,2000) dapat dilakukan sebagai berikut:

\section{Nilai Erosivitas Hujan (R)}

Nilai $\mathrm{R}$ merupakan daya rusak hujan atau erosivitas. Oleh beberapa ahli dicoba untuk memakai data hujan yang umumnya tersedia, karena untuk mendapatkan nilai $\mathrm{R}$ terlebih dahulu diperlukan data curah hujan bulanan, jumlah hari hujan, dan hujan maksimum. Perhitungan nilai erosivitas hujan dilakukan dengan menggunakan data curah hujan 10 tahun dan data tersebut diolah dengan menggunakan persamaan Bols (1978).

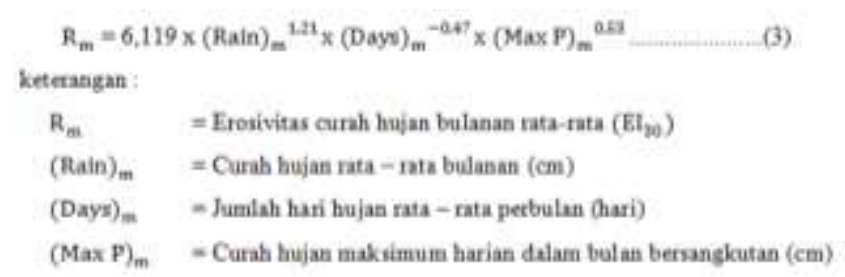

\section{Nilai Erodibilitas Tanah (K)}

Nilai K merupakan kepekaan tanah terhadap erosi atau erodibilitas yaitu mudah tidaknya tanah tererosi yang ditentukan oleh berbagai sifat dan kimia tanah (Arsyad, 2000). Peta erodibilitas tanah dibuat dengan bantuan peta jenis tanah yang diperoleh dari BPDAS Agam Kuantan. Dengan adanya informasi mengenai jenis tanah ini maka dapat ditentukan nilai erodibilitas (K) kemudian dikelompokkan.

\section{Nilai Panjang dan Kemiringan Lereng (LS)}

Nilai faktor topografi (LS) adalah besaran yang menunjukkan perbandingan tanah yang hilang suatu luasan lahan (ton/ha) pada lereng tertentu dengan tanah yang hilang dari suatu petak baku pada tempat yang berdekatan (Rusman, 1999). Penentuan nilai panjang kemiringan lereng ditentukan dari analisis data berupa peta kemiringan lereng yang diperoleh dari BPDAS Agam Kuantan dengan mengklasifikasikan lereng tersebut dalam kelas - kelas berdasarkan nilai kemiringan lereng.

\section{Nilai Faktor Pengelolaan Tanaman dan Tindakan Konservasi (CP)}

Faktor tanaman dan pengelolaan lahan (CP) diperoleh dari data penggunaan lahan dan tindakan konservasi yang dilakukan. Nilai indeks CP didapat dari peta penggunaan lahan kemudian data tersebut disesuaikan dengan pengelompokan nilai faktor CP.

\section{Pembuatan Satuan Lahan}

Satuan lahan merupakan satuan pemetaan dan pengamatan terkecil yang memiki faktor fisik yang sama pada kesatuan lahan dalam artian erosi yang terjadi pada lahan dalam suatu unit lahan tersebut dianggap sama. Pada analisis tiap satuan lahan dibatasi berdasarkan perbedaan kemiringan lereng, jenis penggunaan lahan dan jenis tanah yang terdapat pada daerah penelitian. Penggabungan dengan cara menumpangsusunkan (overlay) peta kelas kelerengan dengan peta jenis penggunaan lahan dan peta jenis tanah merupakan cara untuk menentukan peta satuan lahan. Dengan menggabungkan faktor-faktor fisik tersebut menggunakan SIG maka diperoleh peta satuan lahan.

\section{Analisis Spasial Berdasarkan Metode USLE}

Analisa spasial merupakan proses pemodelan, pengolahan dan interpretasi informasi tentang suatu kenampakan geografik, sehingga membantu untuk menemukan dan memahami hubungan antar data. Selain itu, analisa ini juga mencakup masalah penyajian peta secara overlay pada suatu peta dasar.

Analisis spasial dilakukan dengan menumpangsusunkan (overlay) beberapa data spasial (parameter penentu erosi) dalam bentuk layer untuk menghasilkan unit pemetaan baru yang digunakan sebagai unit analisis yaitu analisis erosi. Pada setiap unit 
analisis tersebut dilakukan analisis berdasarkan data atribut.

Hasil analisis berdasarkan data atribut selanjutnya dikaitkan dengan data spasialnya untuk menghasilkan data spasial perkiraan laju erosi. Perkiraan erosi berdasarkan metode USLE dengan membangun basis data sistem informasi geografis dengan menggunakan teknik tumpang-susun (overlay) terhadap faktor-faktor erosi sehingga diperoleh suatu lapisan informasi baru mengenai perkiraan erosi yang dihasilkan. Kemudian ditentukan tingkat bahaya erosinya berdasarkan hasil yang diperoleh dari perkiraan erosi. Untuk mencapai tujuan itu pengolahan data spasial dengan menggunakan teknologi Sistem Informasi Geografis (SIG) memamfaatkan perangkat lunak ArcGIS 9.3.

Proses tumpang-susun ini dilakukan dengan overlay kesemua layer antara lain : erodibilitas tanah, kemiringan lereng dan penggunaan lahan sehingga dihasilkan sebuah peta baru yaitu peta satuan lahan yang kemudian dioverlay-kan dengan layer erosivitas curah hujan tahunan rata-rata sehingga dihasilkan layer erosi.

\section{Penentuan Kriteria Tingkat Bahaya Erosi}

Setelah pengolahan dan analisis data selesai selanjutnya dilakukan penentuan tingkat bahaya erosi pada tiap satuan lahan dengan perkiraan erosi tahunan dari metode USLE dan erosi yang masih dapat ditoleransi. Perhitungan TBE menggunakan persamaan Hammer (1981). Evaluasi bahaya erosi atau disebut juga tingkat bahaya erosi ditentukan berdasarkan perbandingan antara besarnya erosi tanah aktual dengan erosi tanah yang dapat ditoleransikan. Kriteria tingkat bahaya erosi bermaksud agar dapat diketahui sebaran wilayah besaran tingkat erosi sebagai evaluasi bahaya erosi yang memungkinkan penyusunan rekomendasi tindakan konservasi.

Dari hasil perbandingan antara besar erosi tanah aktual (A) dengan erosi tanah yang dapat ditoleransikan $(\mathrm{T})$ dalam memperoleh nilai Tingkat Bahaya Erosi kemudian nilai TBE tersebut disesuaikan dengan kriteria TBE yang terjadi pada setiap satuan lahannya, dapat dilihat pada Kriteria Tingkat Bahaya Erosi oleh Hammer (1981). Jika besarnya erosi yang terjadi (A) masih dibawah nilai erosi yang dapat ditoleransikan (T), maka tidak akan membahayakan kelestarian sumber daya tanah dan air, akan tetapi jika nilai A lebih besar dari nilai $\mathrm{T}$, maka perlu diperhatikan dan dilakukan tindakan konservasi yang tepat guna menekan dalam mengurangi laju erosi yang terjadi agar tidak membahayakan kondisi pada DAS.

\section{Rencana Arahan Rehabilitas Lahan dan Konservasi Tanah}

Berdasarkan hasil analisis tingkat bahaya erosi tersebut di atas, maka satuan-satuan lahan ditentukan berdasarkan prioritas untuk pelaksanaan praktek penanganan rehabilitasi lahan. Pada kriteria tingkat bahaya erosi tersebut, maka dapat diketahui daerah mana yang menjadi prioritas rehabilitas lahan dan konservasi lahan dalam pengambilan keputusan dalam tindakan konservasi. Sehingga kriteria tingkat bahaya erosi yang memiliki nilai TBE yang sangat tinggi merupakan prioritas pertama sebagai daerah pelaksanaan praktek penanganan rehabilitas lahan dan konservasi tanah. Dari uraian tersebut, terutama tentang Tingkat Bahaya Erosi, maka pada Sub DAS Batang Kandis perlu dibuat pengelompokkan dalam prioritas dalam membuat rekomendasi pelaksanaan praktek penanganan rehabilitas lahan dan tindakan konservasi yang harus ditindak lanjuti sesuai dengan berapa besar nilai bahaya 
erosi berdasarkan kriteria TBE masing masing pada tiap satuan lahannya.

Rekomendasi pelaksanaan praktek penanganan rehabilitas lahan dan tindakan konservasi untuk menurunkan laju erosi aktual dari laju erosi yang diperbolehkan. Sehingga pelaksanaan praktek penanganan arahan rehabilitas lahan dan tindakan konservasi yang diberikan sesuai dengan kemampuan lahan dan kesesuaian dengan fungsi kawasan berdasarkan kriteria yang digunakan oleh Balai Rehabilitasi Lahan dan Konservasi Tanah. Hasil rekomendasi tersebut digambarkan dalam bentuk peta rekomendasi dalam pelaksanaan penanganan rehabilitas lahan dan tindakan konservasi.

Dengan menentukan dan mengarahkan pelaksanaan penanganan rehabilitas lahan dan tindakan konservasi serta pertimbangan dalam penyesuaian tata guna lahan pada setiap satuan lahan terhadap prioritas penanganan tindakan rehabilitas lahan dan konservasi tanah yang dapat diarahkan pemanfaatan lahan serta arahan tindakan konservasi tanah yang sesuai. Oleh karena itu, diperlukan perencanaan pelaksanaan penanganan tersebut dalam pengolahan penggunaan lahan yang baik dan benar, terutama dalam melakukan tindakan terhadap rancangan berkelanjutan dalam pengelolaan DAS tersebut.

\section{HASIL DAN PEMBAHASAN}

\section{Keadaan Umum Daerah Penelitian}

Sub DAS Batang Kandis merupakan daerah penelitian secara administratif terletak di Kecamatan Koto Tangah Kota Padang Sumatera Barat. Secara geografis, Sub DAS Batang Kandis ini terletak antara $100^{\circ} 18^{\prime} 50^{\prime \prime}$ BT - $100^{\circ} 25^{\prime} 10^{\prime \prime}$ BT dan $0^{\circ} 44^{\prime} 35^{\prime \prime}$ LS $0^{\circ} 51 ' 20 "$ LS dengan ketinggian tempat berkisar antara $0-1250 \mathrm{~m}$ dpl dengan luas daerah penelitian yaitu 5506,56 ha. Sub DAS
Batang Kandis di sebelah utara berbatasan dengan DAS Anai, di sebelah selatan dan timur berbatasan dengan DAS Air Dingin dan di sebelah barat berbatasan dengan Samudera Indonesia.

Dilihat dari segi iklim di Sub DAS Batang Kandis ini ditinjau dari klasifikasi iklim Schmidt Ferguson menunjukkan bahwa Sub DAS Batang Kandis memiliki tipe iklim A dengan kategori iklim sangat basah yang memiliki curah hujan yang sangat tinggi dan berdasarkan data curah hujan Stasiun Kasang selama 10 tahun $(2003$ - 2012) curah hujan rata - rata tahunan Sub DAS Batang Kandis sekitar 4588,75 mm/tahun.

Sub DAS Batang Kandis termasuk daerah yang penggunaan lahannya didominasi oleh hutan dengan luasan sekitar 2308,74 Ha, kemudian diikuti dengan perkebunan campuran yang dengan luasan sekitar 2223,14 Ha. Adapun sebagian jenis penggunaan lahan yang lainnya yaitu ladang dengan luasan sekitar 214,40 Ha, semak dan belukar 69,35 Ha, sawah sekitar 519,75 Ha dan permukiman sekitar 164,22 Ha. Jenis penggunaan lahan tersebut dapat dilihat pada Tabel 1 .

Tabel 1. Jenis Penggunaan Lahan di Sub DAS Batang Kandis

\begin{tabular}{|c|c|c|c|}
\hline \multirow{2}{*}{ No } & \multirow{2}{*}{ Penggunaan Lahan } & \multicolumn{2}{|c|}{ Luas } \\
\cline { 3 - 4 } & & Ha & $(\%)$ \\
\hline 1 & Hutan & 2308,74 & 41,98 \\
\hline 2 & Ladang & 214,40 & 3,90 \\
\hline 3 & Perkebunan Campuran & 2223,14 & 40,42 \\
\hline 4 & Permukiman & 164,22 & 2,99 \\
\hline 5 & Sawah & 519,75 & 9,45 \\
\hline 6 & Semak dan Belukar & 69,35 & 1,26 \\
\hline & Jumlah & 5499,59 & 100 \\
\hline
\end{tabular}

Sumber :hasil perhitungan analisis dengan menggunakan SIG.

Berdasarkan penggunaan lahan pada Sub DAS Batang Kandis tersebut yang mana hutan dan perkebunan campuran merupakan penggunaan lahan yang lebih luas daripada penggunaan 
lahan lainnya. Dimana penggunaan lahan hutan dan perkebunan campuran sangat berdekatan letak penggunaan lahannya yang dapat memungkinkan terjadinya kegiatan pembukaan lahan. Apalagi hutan sangat rentan mengalami kegiatan pembukaan lahan untuk dijadikan perkebunan campuran sehingga dapat mengurangi luas hutan. Apabila dengan luasnya perkebunan campuran di Sub DAS Batang Kandis ini diikuti meningkatnya pertumbuhan jumlah penduduknya dalam waktu yang tidak akan lama lahan yang lain di sekitarnya juga dapat beralih fungsi secara cepat maka kemungkinan besar dapat menyebabkan erosi menjadi meningkat. Hal ini sejalan dengan pernyataan Sherbinin (2002) yang mengemukakan bahwa konversi daerah berhutan menjadi lahan-lahan pertanian (perkebunan, kebun campuran, dan ladang), padang rumput atau permukiman penduduk mengakibatkan terganggunya proses hidrologi, meningkatnya aliran permukaan dan menyebabkan peningkatan erosi dan banjir.

\section{Analisa Parameter Prediksi Erosi Pada Sub DAS Batang Kandis}

\section{Erosivitas Hujan (R)}

Faktor iklim yang paling mempengaruhi erosi adalah hujan (Arsyad, 2010). Curah hujan merupakan faktor iklim yang sangat berpengaruh terhadap terjadinya erosi. Arsyad (2010) juga menyatakan bahwa besarnya curah hujan, intensitas, dan distribusi hujan menentukan kekuatan dispersi hujan terhadap tanah, jumlah dan kekuatan aliran permukaan serta tingkat kerusakan erosi yang terjadi.

Dalam menentukan nilai erosivitas hujan diperlukan data curah hujan yang diperoleh dari Dinas PSDA Provinsi Sumatera Barat selama 10 tahun terakhir kemudian dihitung dengan menggunakan rumus Bols. Nilai
Erosivitas Hujan pada Sub DAS Batang Kandis dapat dilihat pada Tabel 2.

Dari hasil perhitungan tersebut diperoleh nilai erosivitas hujan bulanan dalam setahun, selanjutnya dijumlahkan maka didapat nilai erosivitas hujan (R) pada Sub DAS Batang Kandis yang sangat tinggi yaitu sebesar 8748,376. Bila dikaitkan dengan kondisi topografi di Sub DAS Batang Kandis yang mana didaerah hulu Sub DAS tersebut memiliki kelerengan yang curam yang dapat memungkinkan potensi terjadinya aliran permukaan dan erosi oleh air hujan dengan jumlah yang besar dan intensitas curah hujan yang sangat tinggi. Sesuai dengan pernyataan tersebut, menurut Baver (1959) yang menyatakan bahwa erosi akan meningkat dengan bertambahnya panjang lereng pada intensitas hujan tinggi, tetapi erosi akan menurun dengan bertambahnya panjang lereng pada intensitas hujan yang rendah. Dengan kondisi tersebut apabila tanah tidak ditutupi penutup tanah (vegetasi) maka akan semakin meningkat aliran permukaan dan erosi.

Tabel 2. Nilai Erosivitas Hujan pada Sub DAS Batang Kandis

\begin{tabular}{|c|c|c|c|c|c|}
\hline $\begin{array}{l}\mathrm{Bu} \\
\operatorname{lan}\end{array}$ & $\begin{array}{l}\text { Rain } \\
(\mathrm{cm})\end{array}$ & $\begin{array}{l}\text { Days } \\
\text { (hari) }\end{array}$ & $\begin{array}{l}\text { Max } \\
(\mathrm{cm})\end{array}$ & $\begin{array}{c}\text { Erosivitas } \\
\text { Hujan Bulanan }\end{array}$ & $\begin{array}{c}\text { Nilai } \\
\text { R }\end{array}$ \\
\hline 1 & 37,14 & 9,00 & 12,64 & 663,264 & \multirow{12}{*}{$\begin{array}{r}8748 \\
, 376\end{array}$} \\
\hline 2 & 39,02 & 8,33 & 13,46 & 754,443 & \\
\hline 3 & 39,96 & 9,67 & 10,58 & 637,615 & \\
\hline 4 & 34,13 & 8,80 & 12,21 & 594,134 & \\
\hline 5 & 29,06 & 8,33 & 12,27 & 502,954 & \\
\hline 6 & 36,93 & 8,10 & 11,32 & 652,617 & \\
\hline 7 & 34,02 & 7,60 & 12,74 & 648,255 & \\
\hline 8 & 36,55 & 9,50 & 12,85 & 639,574 & \\
\hline 9 & 48,06 & 10,33 & 15,06 & 931,272 & \\
\hline 10 & 59,47 & 13,33 & 12,75 & 979,039 & \\
\hline 11 & 54,29 & 13,00 & 16,28 & 1010,012 & \\
\hline 12 & 45,51 & 11,44 & 11,95 & 735,197 & \\
\hline
\end{tabular}

Sumber : hasil perhitungan 


\section{Erodibilitas Tanah $(\mathbf{K})$}

Erodibilitas tanah adalah kepekaan tanah terhadap erosi. Faktor erodibilitas tanah atau kepekaan tanah sangat berkaitan dengan daya tahan tanah terhadap pukulan butiran air hujan. Jenis tanah yang berbeda memiliki perbedaan tingkat kepekaan terhadap erosi. Maka dari itu dalam menentukan nilai erodiblitas tanah dapat dikelompokkan berdasarkan jenis tanah yang diperoleh dari BPDAS Agam Kuantan. Dari informasi mengenai jenis tanah tersebut maka dapat ditentukan nilai erodibilitas tanah (K) dengan melakukan analisa dan identifikasi sebaran jenis tanah menggunakan perangkat Sistem Informasi Geografis (SIG). Jenis tanah dan nilai erodibilitas tanah dapat dilihat pada Tabel 3.

Berdasarkan hasil analisa tersebut bahwa terdapat 3 jenis tanah di Sub DAS Batang Kandis didominasi jenis tanah Kambisol dengan luasan 4503,39 Ha, kemudian diikuti oleh jenis tanah Glei Humus 600,96 Ha dan jenis tanah Regosol 402,21 Ha. Jenis tanah yang memiliki nilai erodibilitas tanah terbesar terdapat pada jenis tanah Regosol dengan nilai $\mathrm{K}$ sebesar 0,4 termasuk kriteria agak tinggi. Semakin tinggi nilai erodibilitas tanah maka semakin besar pula kemampuan tanah mengalami erosi. Peta sebaran jenis tanah dapat dilihat pada Gambar 1. Disamping itu, Arsyad (2010) juga mengemukakan bahwa sifat tanah yang mempengaruhi nilai erosi adalah erodibilitas tanah dan berbagai tipe tanah mempunyai kepekaan terhadap erosi yang berbeda-beda. Apabila tanah memiliki kemampuan dalam menahan air curahan hujan maka akan sedikit kemungkinan terjadinya erosi begitu juga sebaliknya. Tanah yang erodibilitas tinggi akan peka terhadap erosi dibandingkan dengan tanah yang erodibilitas rendah memiliki daya tahan kuat (resisten) terhadap erosi.
Tabel 3. Jenis Tanah dan Nilai Erodibilitas Tanah (K) di Sub DAS Batang Kandis

\begin{tabular}{|c|c|c|c|c|c|}
\hline \multirow{2}{*}{ No } & \multirow{2}{*}{ Simbol } & \multirow{2}{*}{ Jenis Tanah } & \multirow{2}{*}{ Nilai K } & \multicolumn{2}{|c|}{ Luas } \\
\cline { 5 - 6 } & & & & Ha & $(\%)$ \\
\hline 1 & $\mathrm{Gh}$ & Glei Humus & 0,26 & 600,96 & 10,91 \\
\hline 2 & $\mathrm{~Kb}$ & Kambisol & 0,23 & 4503,39 & 81,78 \\
\hline 3 & $\mathrm{Rg}$ & Regosol & 0,4 & 402,21 & 7,30 \\
\hline \multicolumn{3}{|c|}{ Jumlah } & 5506,56 & 100 \\
\hline
\end{tabular}

Sumber : BPDAS Agam Kuantan dan hasil perhitungan analisis dengan menggunakan SIG.

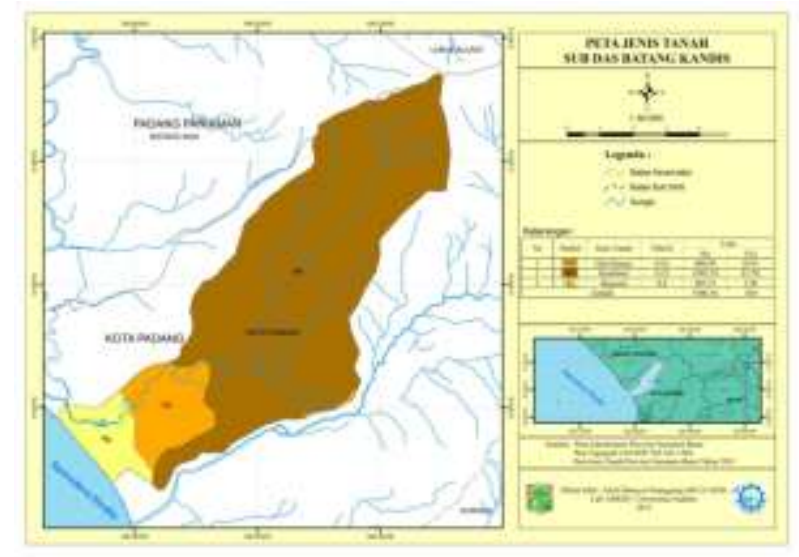

Gambar 1. Peta Jenis Tanah Sub DAS Batang Kandis

\section{Panjang dan Kemiringan Lereng (LS)}

Faktor panjang dan kemiringan lereng merupakan dua faktor dalam unsur topografi yang menentukan kehilangan volume tanah apabila terjadi erosi. Berdasarkan analisa peta kemiringan lereng yang diperoleh dari BPDAS Agam Kuantan menunjukkan bahwa terdapat 2 kelas lereng pada Sub DAS Batang Kandis dapat dilihat pada Gambar 2. Sesuai dari hasil analisa dengan menggunakan SIG, maka pada Sub DAS Batang Kandis kelerengan dengan kisaran 25\% - $40 \%$ (Curam) paling mendominasi dengan luasan 3260,63 Ha. Dikawasan ini terdapat sebagian pemanfaatan lahan areal perkebunan campuran dan pertanian lahan kering. Hal ini akan memberi pengaruh besar dalam meningkatkan erosi yang akan terjadi. Selain itu, Sub Das Batang Kandis juga memiliki kelerengan dengan kisaran 0\% - 8\% (Datar) dengan luasan 2245,93 Ha. Klasifikasi lereng serta nilai 
panjang dan kemiringan lereng dapat dilihat pada Tabel 4.

Tabel 4. Klasifikasi Lereng serta Nilai LS di Sub DAS Batang Kandis

\begin{tabular}{|c|c|c|c|c|c|c|}
\hline \multirow{2}{*}{$\begin{array}{c}\mathrm{N} \\
\mathrm{o}\end{array}$} & \multirow{2}{*}{$\begin{array}{l}\text { Sim } \\
\text { bol }\end{array}$} & \multirow{2}{*}{$\begin{array}{l}\text { Kelas } \\
\text { Lereng }\end{array}$} & \multirow{2}{*}{$\begin{array}{l}\text { Kemiringan } \\
\text { Lereng }\end{array}$} & \multirow{2}{*}{$\begin{array}{l}\text { Nilai } \\
\text { LS }\end{array}$} & \multicolumn{2}{|c|}{ Luas } \\
\hline & & & & & $\mathrm{Ha}$ & $\%$ \\
\hline 1 & Dt & I & $\begin{array}{c}0 \%-8 \% \\
(\text { Datar ) }\end{array}$ & 0,4 & 2245,93 & 40,79 \\
\hline 2 & $\mathrm{Cr}$ & IV & $\begin{array}{c}25 \%-40 \% \\
(\text { Curam ) }\end{array}$ & 6,8 & 3260,63 & 59,21 \\
\hline \multicolumn{5}{|c|}{ Jumlah } & 5506,56 & 100 \\
\hline
\end{tabular}

Sumber : BPDAS Agam Kuantan dan hasil perhitungan analisis dengan menggunakan $S I G$.

Kemiringan dan panjang lereng adalah dua sifat topografi yang paling berpengaruh terhadap aliran permukaan dan erosi (Arsyad, 2010). Maka dari itu semakin panjang suatu lereng akan semakin banyak volume tanah yang terbawa oleh aliran permukaan dan semakin curam kemiringan lereng maka semakin cepat pula aliran permukaan mengangkut tanah. Hal tersebut pun diungkapkan oleh Hardjowigeno (2003) yang menyatakan bahwa erosi akan meningkat apabila lereng semakin curam atau semakin panjang.

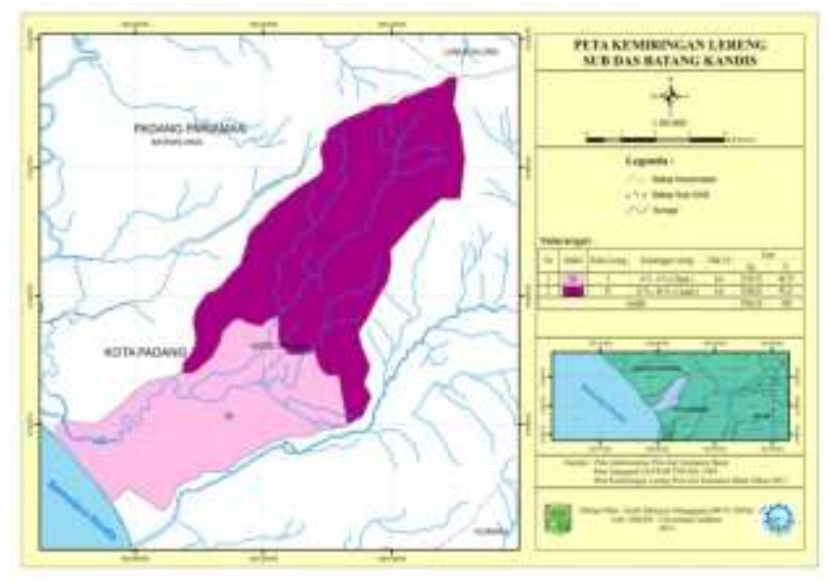

Gambar 2. Peta Kemiringan Lereng Sub DAS Batang Kandis

\section{Pengelolaan Tanaman dan Tindakan Konservasi (CP)}

Faktor selanjutnya yang mempengaruhi erosi dalam melindungi permukaan tanah terhadap kerusakan tanah oleh butir-butir hujan adalah vegetasi penutup tanah. Faktor vegetasi penutup tanah dan pengelolaan tanaman serta tindakan - tindakan konservasi (CP) yang nilainya diperoleh berdasarkan pada jenis penggunaan lahan. Jenis penggunaan lahan yang terdapat pada Sub DAS Batang Kandis didasari pada Peta Penggunaan Lahan Sub DAS Batang Kandis yang diperoleh dari BPDAS Agam Kuantan. Dari peta tersebut kemudian dianalisa dan diidentifikasi menggunakan perangkat SIG untuk menentukan sebaran jenis penggunaan lahan serta dikelompokkan berdasarkan jenis penggunaan lahan untuk menentukan nilai faktor CP.

Dari hasil analisa peta tersebut maka didapat 6 jenis penggunaan lahan yang terdapat pada Sub DAS Batang Kandis yaitu Hutan, Ladang, Perkebunan Campuran, Permukiman, Sawah dan Semak dan Belukar.

Berdasarkan Tabel 5 maka dilihat bahwa setiap penggunaan lahan memiliki nilai $\mathrm{CP}$ yang berbeda-beda. Hal tersebut terlihat pada penggunaan lahan yaitu Semak dan Belukar, Ladang, Perkebunan Campuran dan Sawah yang masing - masing penggunaan lahannya memiliki nilai $\mathrm{CP}$ yang tinggi, dikarenakan tanaman yang ditanam tidak memiliki perakaran yang baik dan kuat dalam menahan erosivitas hujan. Hal ini dapat merusak lapisan permukaan tanah apalagi ditambah dengan kondisi lereng yang curam. Akan tetapi, berbeda dengan jenis penggunaan lahan seperti Hutan yang memiliki nilai CP yang paling rendah dikarenakan mempunyai tajuk dan kerapatan yang tinggi juga perakaran yang kuat sehingga kemampuan dalam menahan erosivitas hujan sangat besar. Peta sebaran jenis penggunaan lahan Sub DAS Batang Kandis dapat dilihat pada Gambar 3. 
Tabel 5. Penggunaan Lahan dan Nilai CP pada Sub DAS Batang Kandis

\begin{tabular}{|c|c|c|c|c|c|}
\hline \multirow{2}{*}{$\begin{array}{l}\mathrm{N} \\
\mathrm{o}\end{array}$} & \multirow{2}{*}{ Simbol } & \multirow{2}{*}{$\begin{array}{c}\text { Penggunaan } \\
\text { Lahan }\end{array}$} & \multirow{2}{*}{$\begin{array}{c}\text { Nilai } \\
\text { CP }\end{array}$} & \multicolumn{2}{|c|}{ Luas } \\
\hline & & & & $\mathrm{Ha}$ & $(\%)$ \\
\hline 1 & $\mathrm{Ht}$ & Hutan & 0,001 & 2308,74 & $\begin{array}{c}41,9 \\
8\end{array}$ \\
\hline 2 & $\mathrm{Ld}$ & Ladang & 0,07 & 214,40 & 3,90 \\
\hline 3 & $\mathrm{Kc}$ & $\begin{array}{c}\text { Perkebunan } \\
\text { Campuran }\end{array}$ & 0,02 & 2223,14 & $\begin{array}{c}40,4 \\
2\end{array}$ \\
\hline 4 & $\mathrm{Pm}$ & Permukiman & 0,05 & 164,22 & 2,99 \\
\hline 5 & Sw & Sawah & 0,01 & 519,75 & 9,45 \\
\hline 6 & B & $\begin{array}{l}\text { Semak dan } \\
\text { Belukar }\end{array}$ & 0,1 & 69,35 & 1,26 \\
\hline & & Jumlah & & 5499,59 & 100 \\
\hline
\end{tabular}

Sumber : BPDAS Agam Kuantan dan hasil perhitungan analisis dengan menggunakan SIG.

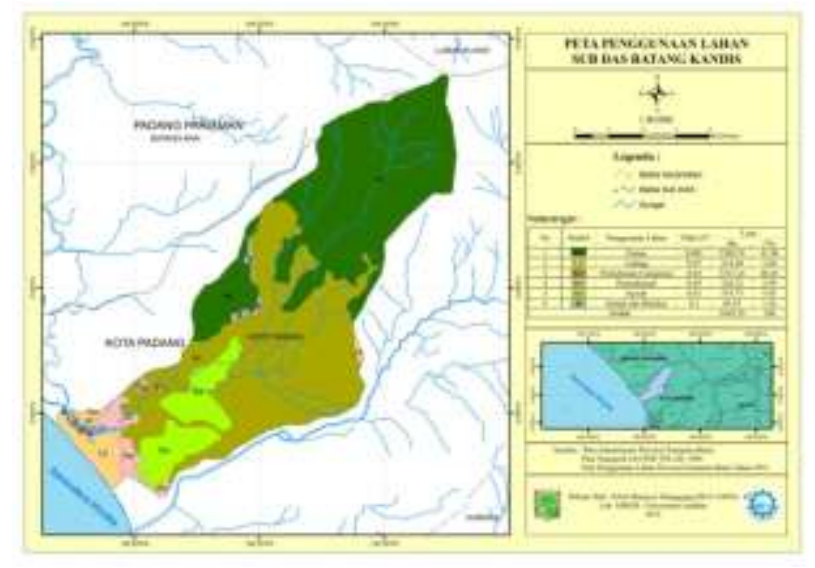

Gambar 3. Peta Penggunaan Lahan Sub DAS Batang Kandis

Hal tersebut didukung oleh Hardjowigeno (2003) yang mengatakan bahwa vegetasi mempunyai pengaruh yang besar terhadap erosi karena vegetasi menghalangi air hujan agar tidak jatuh langsung di permukaan tanah, sehingga kekuatan untuk menghancurkan tanah sangat dikurangi. Akan tetapi, dalam pengaruh vegetasi penutup tanah tersebut perlu juga dilihat ketinggian tajuk dan kerapatan tajuk yang mempengaruhi butiran-butiran hujan yang menimpa permukaan tanah. Selain itu, perakaran tanaman sangat berperan sebagai pemantapan agregat dan memperbesar porositas tanah. Sesuai dengan pendapat Utomo (1989) yang menyatakan bahwa pengaruh vegetasi sangat tergantung pada jenis tanaman, perakaran, tinggi tanaman, tajuk dan tingkat pertumbuhannya.

\section{Satuan Lahan Sub DAS Batang Kandis}

Dalam mendapatkan suatu unit lahan ataupun satuan lahan Sub DAS Batang Kandis diperoleh berdasarkan hasil analisis peta jenis tanah, peta kemiringan lereng dan peta penggunaan lahan. Selanjutnya dilakukan penggabungan dengan cara menumpangsusunkan (overlay) berdasarkan ketiga peta tersebut dengan menggunakan perangkat Sistem Informasi Geografis (SIG) sehingga hasil dari penggabungan ketiga peta tersebut maka diperoleh peta satuan lahan Sub DAS Batang Kandis yang dapat dilihat pada Tabel 6.

Berdasarkan hasil penggabungan ketiga peta tersebut maka satuan lahan Sub DAS Batang Kandis diperoleh 18 satuan lahan yang mana luasan terbesar pada satuan lahan tersebut terdapat pada satuan lahan $\mathrm{KCH}$ dengan luasan 2298,595 Ha. Diikuti pada satuan lahan KDK dengan luasan 1029,770 Ha. Pada satuan lahan $\mathrm{KCH}$ merupakan satuan lahan yang penggunaan lahannya adalah hutan yang memiliki kelas kelerengan yang curam sekitar $25 \%$ - $40 \%$ dengan jenis tanah kambisol. Sedangkan pada satuan lahan KDK yang merupakan penggunaan lahannya adalah kebun campuran yang memilki kelas kelerangan yang datar sekitar $0 \%-8 \%$ dengan jenis tanah kambisol. Dari Tabel 6 tersebut juga terlihat bahwa dari jumlah 18 satuan lahan berdasarkan penggunaan lahan yang terdapat pada Sub DAS Batang Kandis menunjukkan ada 5 satuan lahan dengan penggunaan lahan kebun campuran yang paling mendominasi dibandingkan penggunaan lahan lainnya. Akan tetapi, dari 5 satuan lahan tersebut memiliki tingkat kelerengan dan jenis tanah yang berbeda pula. Seperti yang terdapat pada satuan lahan KDK yang memiliki kesamaan dengan satuan lahan GCK terhadap penggunaan lahan yaitu kebun campuran, akan tetapi satuan lahan GCK 
memiliki topografi yang curam dengan jenis tanah glei humus dan begitu juga seterusnya pada tiap satuan unit lahan. Dari setiap keseluruhan satuan lahan tersebut pasti nantinya akan memiliki perbedaan laju erosi terhadap pengaruh penggunaan lahan, kelerengan dan jenis tanah yang berbeda beda.

Selanjutnya dari peta satuan lahan yang dapat dilihat pada Gambar 4 ini akan digunakan sebagai acuan dalam menentukan nilai laju erosi yang terjadi pada masing - masing satuan lahan di Sub DAS Batang Kandis.

\section{Analisis Pendugaan Erosi dengan menggunakan Metode USLE}

Dalam memperoleh nilai laju erosi perlu dilakukan perhitungan berdasarkan persatuan lahan dengan menggunakan metode USLE. Analisis pendugaan erosi Sub DAS Batang Kandis diperoleh dari perkalian nilai faktor - faktor erosi dengan rumusan metode USLE yaitu faktor Erosivitas Hujan (R), faktor Erodibilitas Tanah (K), faktor Panjang dan Kemiringan Lereng (LS) dan faktor Penggunaan dan Pengelolaan Tanah (CP).

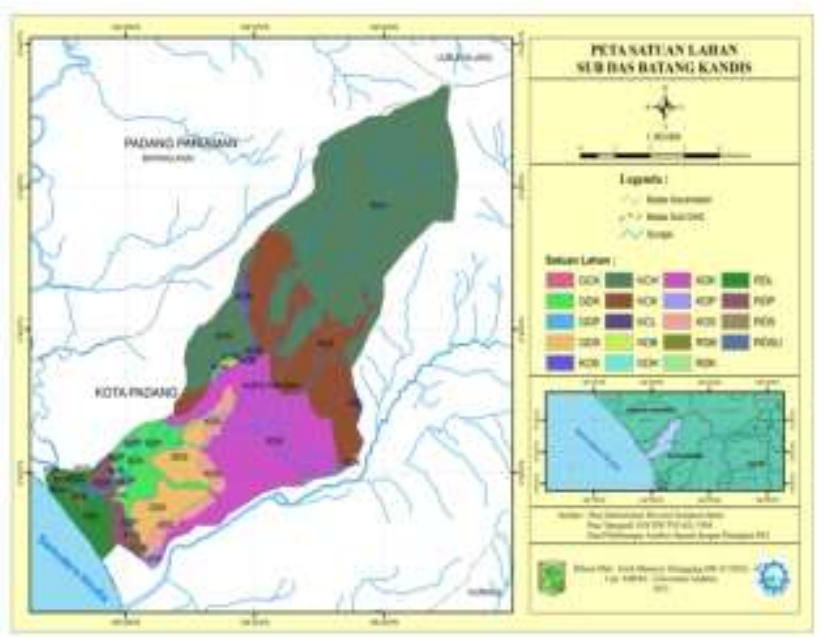

Gambar 4. Peta Satuan Lahan Sub DAS Batang Kandis

Tabel 6. Satuan Lahan Sub DAS Batang Kandis

\begin{tabular}{|c|c|c|c|c|c|c|}
\hline No & Satuan Lahan & Tata Guna Lahan & Lereng & Keterangan & Jenis Tanah & Luas $(\mathrm{Ha})$ \\
\hline 1 & GCK & Perkebunan Campuran & $25 \%-40 \%$ & $\mathrm{Curam}$ & Glei Humus & 7,379 \\
\hline 2 & GDK & Perkebunan Campuran & $0 \%-8 \%$ & $\mathrm{D}$ a $\mathrm{tar}$ & Glei Humus & 253,622 \\
\hline 3 & GDP & Permukiman & $0 \%-8 \%$ & $\mathrm{D}$ a t a r & Glei Humus & 25,526 \\
\hline 4 & GDS & Sawah & $0 \%-8 \%$ & $\mathrm{D}$ a t a r & Glei Humus & 314,434 \\
\hline 5 & $\mathrm{KCB}$ & Semak dan Belukar & $25 \%-40 \%$ & $\mathrm{Curam}$ & Kambisol & 33,464 \\
\hline 6 & $\mathrm{KCH}$ & Hutan & $25 \%-40 \%$ & Curam & Kambisol & 2298,595 \\
\hline 7 & $\mathrm{KCK}$ & Perkebunan Campuran & $25 \%-40 \%$ & $\mathrm{Curam}$ & Kambisol & 908,746 \\
\hline 8 & $\mathrm{KCL}$ & Ladang & $25 \%-40 \%$ & Curam & Kambisol & 12,449 \\
\hline 9 & KDB & Semak dan Belukar & $0 \%-8 \%$ & $\mathrm{D}$ a t a r & Kambisol & 8,034 \\
\hline 10 & $\mathrm{KDH}$ & Hutan & $0 \%-8 \%$ & $\mathrm{D}$ a t a r & Kambisol & 10,141 \\
\hline 11 & KDK & Perkebunan Campuran & $0 \%-8 \%$ & $\mathrm{D}$ a t a r & Kambisol & 1029,770 \\
\hline 12 & KDP & Permukiman & $0 \%-8 \%$ & $\mathrm{D}$ a t a r & Kambisol & 14,178 \\
\hline 13 & KDS & Sawah & $0 \%-8 \%$ & $\mathrm{D}$ a t a r & Kambisol & 188,014 \\
\hline 14 & $\mathrm{RDB}$ & Semak dan Belukar & $0 \%-8 \%$ & $\mathrm{D}$ a t a r & Regosol & 27,887 \\
\hline 15 & RDK & Perkebunan Campuran & $0 \%-8 \%$ & $\mathrm{D}$ a t a r & Regosol & 23,625 \\
\hline 16 & RDL & Ladang & $0 \%-8 \%$ & $\mathrm{D}$ a t a r & Regosol & 202,003 \\
\hline 17 & RDP & Permukiman & $0 \%-8 \%$ & $\mathrm{D}$ a t a r & Regosol & 124,431 \\
\hline 18 & RDS & Sawah & $0 \%-8 \%$ & $\mathrm{D}$ a t a r & Regosol & 17,300 \\
\hline \multicolumn{6}{|c|}{ Jumlah } & 5499,599 \\
\hline
\end{tabular}


Dari hasil sebelumnya sudah diperoleh peta satuan lahan yang merupakan hasil dari penggabungan dengan menumpangsusunkan (overlay) ketiga faktor - faktor erosi tersebut kemudian dimasukkan nilai hasil dari analisis faktor erosivitas hujan kedalam perkalian faktor - faktor erosi berdasarkan metode USLE melalui data atribut pada satuan lahan sehingga dihasilkan laju erosi Sub DAS Batang Kandis pada tiap satuan lahan. Nilai laju erosi persatuan lahan dapat disajikan pada Tabel 7. Adapun peta laju erosi dapat dilihat pada Gambar 5.

Berdasarkan analisa pendugaan erosi dengan menggunakan metode USLE pada setiap satuan lahan maka nilai laju erosi terbesar terjadi pada satuan lahan KCB dengan nilai laju erosi sekitar 1368,246 ton/ha/tahun atau $114,02 \mathrm{~mm} /$ tahun termasuk dalam kategori sangat berat dimana penggunaan lahannya adalah semak dan belukar pada tingkat kelerengan 25\%-40\% (Curam) dengan jenis tanah kambisol.

Kemudian diikuti satuan lahan KCL dengan laju erosi sekitar 957,772 ton/ha/tahun atau $79,81 \mathrm{~mm} /$ tahun yang termasuk kedalam kategori sangat berat dimana penggunaan lahannya adalah ladang yang merupakan tanaman pertanian lahan kering pada tingkat kelerengan 25\%-40\% (Curam) dengan jenis tanah kambisol. Dari hasil yang diketahui pada kedua satuan lahan diatas yang memiliki nilai laju erosi terbesar jika dibandingkan dengan satuan lahan $\mathrm{KCH}$ yang memiliki tingkat kelerengan dan jenis tanah yang sama, akan tetapi dari satuan lahan tersebut tidak memiliki kesamaan yang terletak pada penutup lahannya dimana satuan lahan $\mathrm{KCH}$ memiliki penggunaan lahan yaitu hutan yang nilai laju erosi terjadi sebesar 13,682 ton/ha/tahun yang dalam kategori laju erosi sangat ringan. Dalam hal ini berdasarkan pernyataan Kironoto (2003), dimana laju erosi yang terjadi lebih besar dari 480 ton/ha/tahun dapat dikategorikan dalam kelas laju erosi sangat berat sedangkan laju erosi yang terjadi antara 180 - 480 ton/ha/tahun dapat dikategorikan dalam kelas laju erosi berat dan laju erosi yang terjadi lebih kecil dari 15 ton/ha/tahun dapat dikategorikan dalam kelas laju erosi sangat ringan.

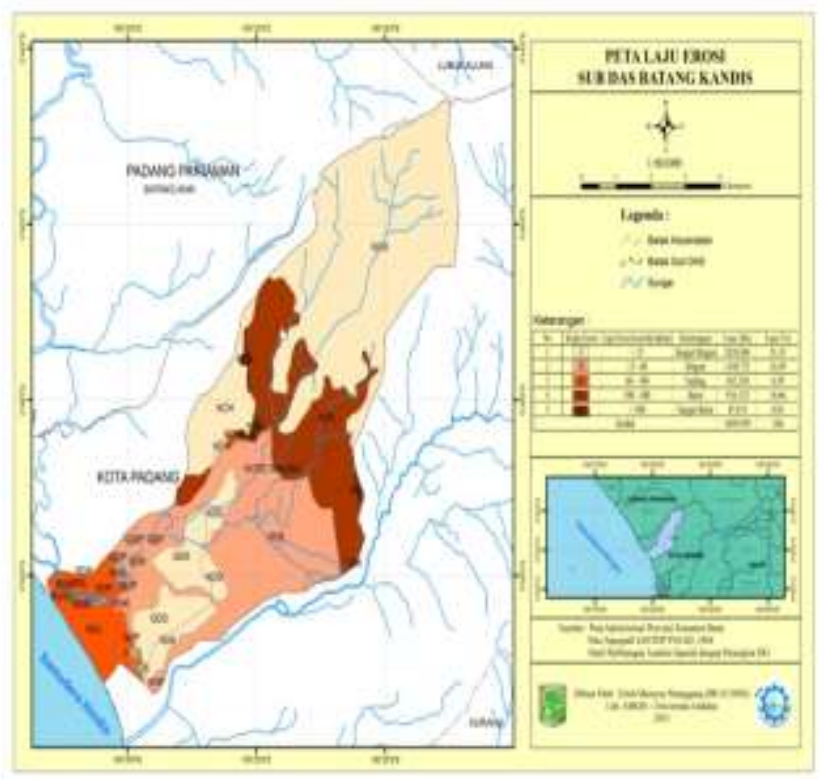

Gambar 5. Peta Laju Erosi Sub DAS Batang Kandis

Dari sini dapat terlihat bahwa tingginya nilai erosi yang terjadi pada satuan lahan yang diatas sangat berkaitan dengan penutup lahannya yaitu vegetasi yang memiliki kerapatan tajuk yang rendah dibandingkan dengan hutan yang memiliki tajuk dan

kerapatan yang tinggi. Hal ini sesuai dengan pendapat Arsyad (2010) yang mengemukakan bahwa ketinggian tajuk dan kerapatan tajuk akan menutupi permukaan tanah terhadap besarnya pengaruh erosivitas butir-butir hujan dalam mengurangi energi tumbukkan yang sampai ke permukaan tanah. Disamping itu faktor kelerengan juga dapat berpengaruh terhadap tingginya nilai laju erosi pada setiap satuan lahan terlihat pada kedua satuan lahan GCK dan GDK yang memiliki tingkat 
kelerengan yang berbeda yaitu curam dan datar dimana nilai laju erosi pada satuan lahan GCK lebih besar daripada satuan lahan GDK dimana nilai laju erosi pada satuan lahan GCK termasuk kedalam kategori berat sekitar 309,343 ton/ha/tahun sedangkan nilai laju erosi pada satuan lahan GDK sekitar 18,197 ton/ha/tahun termasuk kedalam kategori laju erosi ringan padahal jenis penggunaan lahan dan jenis tanah kedua satuan lahan tersebut memiliki kesamaan. Maka dari itu sesuai dengan pendapat Suratman (2008) yang menyatakan bahwa dengan lereng yang terjal pada bagian - bagian tertentu suatu lahan sangat riskan terhadap bahaya erosi.

Tabel 7. Perhitungan Laju Erosi di Sub DAS Batang Kandis pada tiap satuan lahan

\begin{tabular}{|c|c|c|c|c|c|c|c|c|c|}
\hline \multirow[t]{2}{*}{ No } & \multirow{2}{*}{$\begin{array}{l}\text { Satuan } \\
\text { Lahan }\end{array}$} & \multirow{2}{*}{$\begin{array}{c}\text { Nilai } \\
\text { Erosivitas } \\
(\mathrm{R})\end{array}$} & \multirow{2}{*}{$\begin{array}{c}\text { Nilai } \\
\text { Erodibilitas } \\
(\mathrm{K})\end{array}$} & \multirow{2}{*}{$\begin{array}{l}\text { Nilai Faktor } \\
\text { Lereng (LS) }\end{array}$} & \multirow{2}{*}{$\begin{array}{c}\text { Nilai Faktor } \\
\text { Tata Guna } \\
\text { Lahan (CP) }\end{array}$} & \multirow{2}{*}{$\begin{array}{l}\text { Luas } \\
(\mathrm{Ha})\end{array}$} & \multicolumn{3}{|c|}{ Erosi } \\
\hline & & & & & & & ton/Ha/tahun & Ket & ton/tahun \\
\hline 1 & GCK & 8748,376 & 0,26 & 6,8 & 0,02 & 7,379 & 309,343 & berat & 2282,605 \\
\hline 2 & GDK & 8748,376 & 0,26 & 0,4 & 0,02 & 253,622 & 18,197 & ringan & 4615,064 \\
\hline 3 & GDP & 8748,376 & 0,26 & 0,4 & 0,05 & 25,526 & 45,492 & tingan & 1161,202 \\
\hline 4 & GDS & 8748,376 & 0,26 & 0,4 & 0,001 & 314,434 & 9,098 & $\begin{array}{l}\text { sangat } \\
\text { ringan }\end{array}$ & 2860,818 \\
\hline 5 & $\mathrm{KCB}$ & 8748,376 & 0,23 & 6,8 & 0,1 & 33,464 & 1368,246 & $\begin{array}{c}\text { sangat } \\
\text { berat }\end{array}$ & 45787,053 \\
\hline 6 & $\mathrm{KCH}$ & 8748,376 & 0,23 & 6,8 & 0,001 & 2298,595 & 13,682 & $\begin{array}{l}\text { sangat } \\
\text { ringan }\end{array}$ & 31450,434 \\
\hline 7 & KCK & 8748,376 & 0,23 & 6,8 & 0,02 & 908,746 & 273,649 & berat & $\begin{array}{c}248677,61 \\
7\end{array}$ \\
\hline 8 & KCL & 8748,376 & 0,23 & 6,8 & 0,07 & 12,449 & 957,772 & $\begin{array}{c}\text { sangat } \\
\text { berat }\end{array}$ & 11923,115 \\
\hline 9 & KDB & 8748,376 & 0,23 & 0,4 & 0,1 & 8,034 & 80,485 & sedang & 646,635 \\
\hline 10 & $\mathrm{KDH}$ & 8748,376 & 0,23 & 0,4 & 0,001 & 10,141 & 0,805 & $\begin{array}{l}\text { sangat } \\
\text { ringan }\end{array}$ & 8,162 \\
\hline 11 & KDK & 8748,376 & 0,23 & 0,4 & 0,02 & 1029,77 & 16,097 & ringan & 16756,22 \\
\hline 12 & KDP & 8748,376 & 0,23 & 0,4 & 0,05 & 14,178 & 40,243 & ringan & 570,588 \\
\hline 13 & KDS & 8748,376 & 0,23 & 0,4 & 0,01 & 188,014 & 8,049 & $\begin{array}{l}\text { sangat } \\
\text { ringan }\end{array}$ & 1513,235 \\
\hline 14 & RDB & 8748,376 & 0,4 & 0,4 & 0,1 & 27,887 & 139,974 & sedang & 3903,462 \\
\hline 15 & RDK & 8748,376 & 0,4 & 0,4 & 0,02 & 23,625 & 27,995 & ringan & 661,338 \\
\hline 16 & RDL & 8748,376 & 0,4 & 0,4 & 0,07 & 202,003 & 97,982 & sedang & 19792,652 \\
\hline 17 & $\mathrm{RDP}$ & 8748,376 & 0,4 & 0,4 & 0,05 & 124,431 & 69,987 & sedang & 8708,574 \\
\hline 18 & RDS & 8748,376 & 0,4 & 0,4 & 0,01 & 17,3 & 13,997 & $\begin{array}{l}\text { sangat } \\
\text { ringan }\end{array}$ & 242,154 \\
\hline \multicolumn{5}{|c|}{ Jumlah luas satuan lahan pada Sub Das Batang Kandis } & \multicolumn{5}{|c|}{5499,599} \\
\hline \multicolumn{5}{|c|}{ Jumlah erosi pada Sub DAS Batang Kandis (ton/tahun) } & \multicolumn{5}{|c|}{401380,93} \\
\hline \multicolumn{5}{|c|}{ Erosi rata-rata pada Sub DAS Batang Kandis (ton/Ha/tahun) } & \multicolumn{5}{|c|}{72,984} \\
\hline
\end{tabular}

Sumber : hasil perhitungan analisis dengan menggunakan SIG.

\section{Analisis dan Penentuan Tingkat Bahaya Erosi (TBE)}

Dari nilai laju erosi persatuan lahan tersebut kemudian dilakukan pengelompokkan berdasarkan tingkat bahaya erosi pada tiap satuan lahan yang bertujuan untuk mengetahui potensi erosi tanah yang terjadi pada Sub DAS Batang Kandis. Perhitungan tingkat bahaya erosi dengan membandingkan hasil prediksi erosi yang terjadi (A) menggunakan metode USLE dengan erosi yang ditoleransikan (T). Besarnya nilai erosi yang ditoleransikan (T) diperoleh berdasarkan penelitian Hadjowigeno (2003) yang mengemukakan bahwa dapat ditetapkan besarnya $\mathrm{T}$ maksimum untuk tanah 
- tanah di Indonesia adalah 2,5 mm/tahun atau setara dengan 30 ton/ha/tahun.

Berdasarkan Tabel 8. hasil tingkat bahaya erosi menunjukkan bahwa dari 18 satuan lahan Sub DAS Batang Kandis terdapat 3 satuan lahan dengan bahaya erosi yang sangat tinggi, diikuti dengan 2 satuan lahan dengan bahaya erosi yang tinggi, kemudian 5 satuan lahan dengan bahaya erosi yang sedang dan 8 satuan lahan dengan bahaya erosi yang ringan.

Tabel 8. Perhitungan Tingkat Bahaya Erosi pada Tiap Satuan Lahan di Sub DAS Batang Kandis

\begin{tabular}{|c|c|c|c|c|c|c|}
\hline \multirow{2}{*}{ No } & \multirow{2}{*}{ Satuan Lahan } & Luas & Laju Erosi (A) & T maksimum & \multirow{2}{*}{ Nilai TBE } & \multirow{2}{*}{ Kriteria TBE } \\
\cline { 3 - 5 } & & $(\mathrm{Ha})$ & (ton/ha/tahun) & (ton/ha/tahun) & & \\
\hline 1 & GCK & 7,379 & 309,343 & 30 & 10,31 & Sangat Tinggi \\
\hline 2 & GDK & 253,622 & 18,197 & 30 & 0,61 & Rendah \\
\hline 3 & GDP & 25,526 & 45,492 & 30 & 1,52 & Sedang \\
\hline 4 & GDS & 314,434 & 9,098 & 30 & 0,30 & Rendah \\
\hline 5 & KCB & 33,464 & 1368,246 & 30 & 45,61 & Sangat Tinggi \\
\hline 6 & KCH & 2298,595 & 13,682 & 30 & 0,46 & Rendah \\
\hline 7 & KCK & 908,746 & 273,649 & 30 & 9,12 & Tinggi \\
\hline 8 & KCL & 12,449 & 957,772 & 30 & 31,93 & Sangat Tinggi \\
\hline 9 & KDB & 8,034 & 80,485 & 30 & 2,68 & Sedang \\
\hline 10 & KDH & 10,141 & 0,805 & 30 & 0,03 & Rendah \\
\hline 11 & KDK & 1029,770 & 16,097 & 30 & 0,54 & Rendah \\
\hline 12 & KDP & 14,178 & 40,243 & 30 & 1,34 & Sedang \\
\hline 13 & KDS & 188,014 & 8,049 & 30 & 0,27 & Rendah \\
\hline 14 & RDB & 27,887 & 139,974 & 30 & 4,67 & Tinggi \\
\hline 15 & RDK & 23,625 & 27,995 & 30 & 0,93 & Rendah \\
\hline 16 & RDL & 202,003 & 97,982 & 30 & 3,27 & Sedang \\
\hline 17 & RDP & 124,431 & 69,987 & 30 & 2,33 & Sedang \\
\hline 18 & RDS & 17,300 & 13,997 & 30 & 0,47 & Rendah \\
\hline
\end{tabular}

Sumber : hasil perhitungan analisis dengan menggunakan SIG.

Adapun peta tingkat bahaya erosi dapat dilihat pada Gambar 6. Dengan didapatnya tingkat bahaya erosi berdasarkan luasan keseluruhan Sub DAS Batang Kandis maka diketahui bahwa 75,20 \% luasan Sub DAS Batang Kandis sebagai daerah dengan bahaya erosi yang rendah dengan luas 4135,502 Ha, kemudian 6,80 \% luasan Sub DAS Batang Kandis sebagai daerah dengan bahaya erosi yang sedang dengan luas 374,172 Ha, diikuti $17,03 \%$ luasan Sub DAS Batang Kandis sebagai daerah dengan bahaya erosi yang tinggi dengan luas 936,633 $\mathrm{Ha}$, dan yang terakhir 0,97 \% luasan Sub DAS Batang Kandis sebagai daerah dengan bahaya erosi yang sangat tinggi dengan luas 53,292 Ha. Jika dilihat pada satuan lahan tersebut yang memiliki nilai laju erosi yang lebih kecil dibanding dengan erosi yang ditoleransi maka daerah ini memiliki penggunaan lahan hutan dan sawah, sedangkan daerah yang memiliki penggunaan lahan yaitu ladang (pertanian lahan kering), perkebunan campuran, semak belukar dengan kemiringan lereng curam memiliki nilai laju erosi yang lebih besar dibanding dengan erosi yang ditoleransi. Hal 
tersebut dikemukakan Rusman (1999) yang menyatakan bahwa vegetasi merupakan salah satu faktor penting dalam mempengaruhi besar kecilnya erosi disuatu tempat.

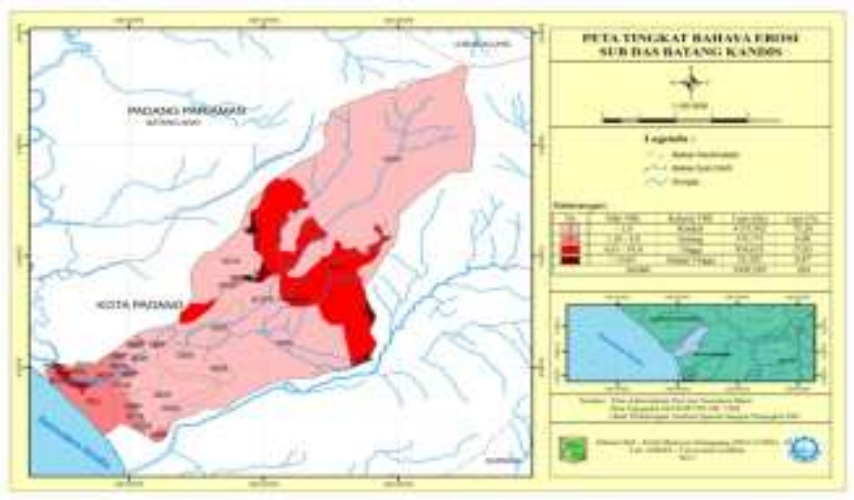

Gambar 6. Peta Tingkat Bahaya Erosi Sub DAS Batang Kandis

Dari nilai tingkat bahaya erosi yang diperoleh maka upaya tindakan konservasi yang akan dilakukan dapat ditentukan berdasarkan arahan penggunaan lahan sesuai dengan kemampuannya yang merupakan salah satu strategi konservasi tanah yang diterapkan oleh Departemen Kehutanan. Dengan arahan penggunaan lahan yang lebih ditekankan pada fungsi masing - masing kawasan yang merupakan salah satu pola rehabilitas lahan dan konservasi tanah (RLKT). Dalam memperoleh status kawasan berdasarkan fungsi tersebut berkaitan dengan karakteristik fisik yaitu kemiringan lereng, jenis tanah menurut kepekaannya terhadap erosi dan curah hujan harian rata - rata pada Sub DAS Batang Kandis. Faktor kemiringan lereng, jenis tanah menurut kepekaannya terhadap erosi dan curah hujan harian rata - rata didapat berdasarkan kelas dan nilai skor masing-masing arahan RLKT dapat dilihat pada Tabel 9,10 dan 11.

Tabel 9. Skor Kemiringan Lereng Arahan RLKT pada Sub DAS Batang Kandis

\begin{tabular}{|c|c|c|c|c|}
\hline \multirow{2}{*}{ Kelas } & \multirow{2}{*}{$\begin{array}{c}\text { Kemiringan } \\
\text { Lereng }\end{array}$} & \multirow{2}{*}{$\begin{array}{c}\text { Nilai } \\
\text { Skor }\end{array}$} & \multicolumn{2}{|c|}{ Luas } \\
\cline { 4 - 5 } & & Ha & $(\%)$ \\
\hline Kelas 1 & $0 \%-8 \%$ & 20 & 2245,93 & 40,79 \\
\hline Kelas 4 & $25 \%-45 \%$ & 80 & 3260,63 & 59,21 \\
\hline \multicolumn{3}{|c|}{ Jumlah } & 5506,56 & 100 \\
\hline
\end{tabular}

Sumber : Hasil perhitungan analisis dengan menggunakan SIG.

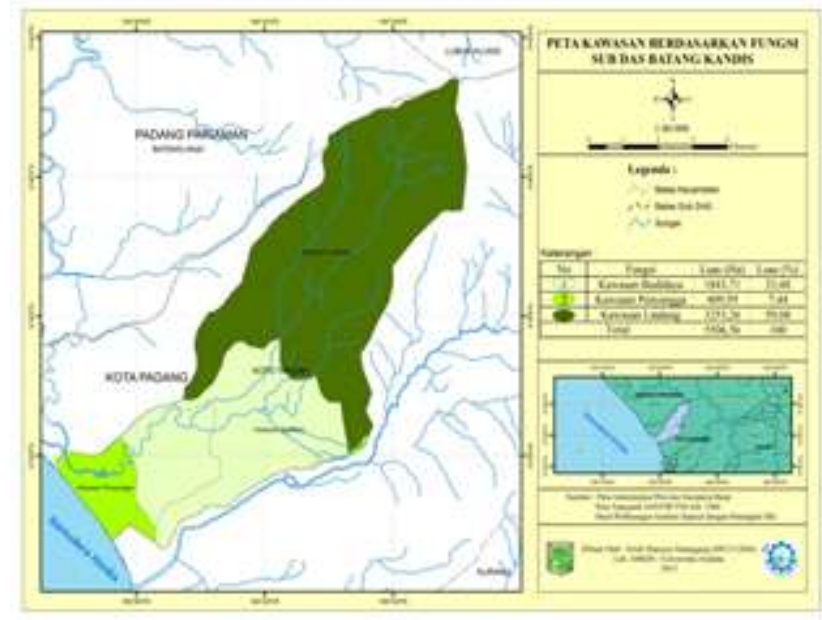

Gambar 7. Peta Kawasan Berdasarkan Fungsi Sub DAS Batang Kandis

Tabel 10. Skor Tanah menurut Kepekaannya Terhadap Erosi Arahan RLKT pada Sub DAS Batang Kandis

\begin{tabular}{|c|c|c|c|c|}
\hline \multirow{2}{*}{ Kelas } & \multirow{2}{*}{$\begin{array}{l}\text { Tanah menurut } \\
\text { kepekaannya } \\
\text { terhadap erosi }\end{array}$} & \multirow{2}{*}{$\begin{array}{l}\text { Nilai } \\
\text { Skor }\end{array}$} & \multicolumn{2}{|c|}{ Luas } \\
\hline & & & $\mathrm{Ha}$ & $(\%)$ \\
\hline Kelas 1 & Glei Humus & 15 & 600,96 & 10,91 \\
\hline Kelas 3 & Kambisol & 45 & 4503,39 & 81,78 \\
\hline Kelas 5 & Regosol & 75 & 402,21 & 7,30 \\
\hline \multicolumn{3}{|c|}{ Jumlah } & 5506,56 & 100 \\
\hline
\end{tabular}

Sumber : Hasil perhitungan analisis dengan menggunakan SIG.

Tabel 11. Skor Intensitas Hujan Harian Rata-rata Arahan RLKT pada Sub DAS Batang Kandis

\begin{tabular}{|c|c|c|c|c|}
\hline \multirow{2}{*}{ Kelas } & \multirow{2}{*}{$\begin{array}{c}\text { Intensitas Hujan } \\
\text { Harian Rata - rata }\end{array}$} & \multirow{2}{*}{$\begin{array}{c}\text { Nilai } \\
\text { Skor }\end{array}$} & \multicolumn{2}{|c|}{ Luas } \\
\cline { 4 - 5 } & Ha & $(\%)$ \\
\hline $\begin{array}{c}\text { Kelas } \\
5\end{array}$ & $42,06 \mathrm{~mm} / \mathrm{hari}$ & 50 & $\begin{array}{c}5506, \\
56\end{array}$ & 100 \\
\hline
\end{tabular}

Sumber : Hasil perhitungan analisis dengan menggunakan SIG.

Suatu kawasan fungsional diperoleh dengan menjumlahkan nilai skor ketiga faktor diatas dengan menggunakan perangkat lunak SIG. Berdasarkan hasil dari perhitungan tersebut pada Tabel 12, maka diperoleh status kawasan berdasarkan fungsi di Sub DAS Batang Kandis berupa peta kawasan berdasarkan fungsi (Gambar 7) yang selanjutnya akan dilakukan analisa identifikasi dengan peta sebaran tingkat bahaya erosi (Gambar 6) tersebut melalui penggabungan kedua peta tersebut 
dengan menggunakan perangkat SIG untuk mengetahui daerah yang menjadi prioritas konservasi pada Sub DAS Batang Kandis maka didapat daerah arahan yang menjadi prioritas rehabilitas lahan dan konservasi tanah di Sub DAS Batang Kandis sebagai dasar berupa peta arahan RLKT dapat dilihat pada Gambar 8.

Prioritas arahan RLKT tersebut didasari pada tingkat bahaya erosi berdasarkan perbandingan antara laju erosi aktual dengan erosi yang ditoleransi selanjutnya diidentifikasi dengan kawasan berdasarkan fungsi di Sub DAS Batang Kandis. Sehingga klasifikasi tingkat bahaya erosi yang sangat tinggi terjadi pada kawasan lindung merupakan prioritas yang utama sebagai daerah konservasi. Akan tetapi, apabila laju erosi aktual lebih kecil daripada erosi yang ditoleransi maka suatu tindakan konservasi lahan tidak perlu dilakukan.

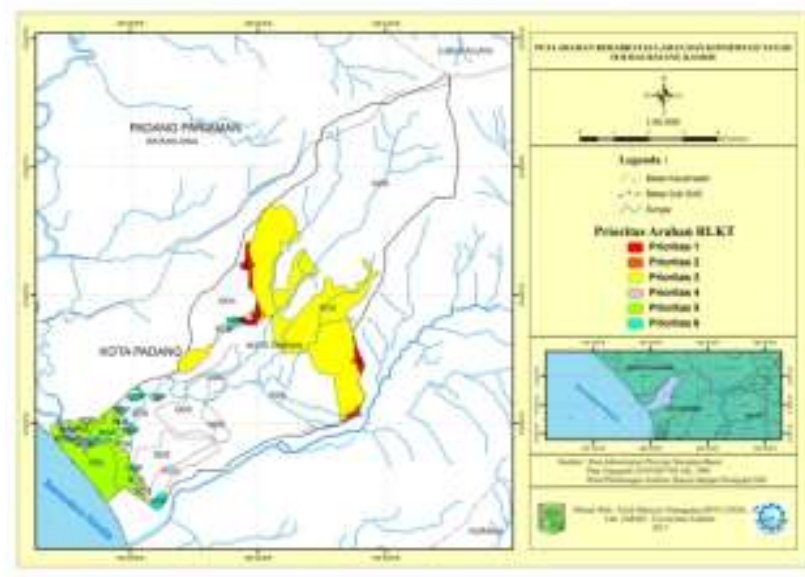

Gambar 8. Peta Arahan Rehabilitas Lahan dan Konservasi Tanah

Tabel 12. Perhitungan Status Kawasan Berdasarkan Fungsi di Sub DAS Batang Kandis

\begin{tabular}{|c|c|c|c|c|c|c|c|c|c|}
\hline \multirow{2}{*}{$\begin{array}{c}\mathrm{N} \\
\mathrm{o}\end{array}$} & \multirow{2}{*}{\multicolumn{2}{|c|}{$\begin{array}{c}\begin{array}{c}\text { Kemiringan } \\
\text { Lereng }\end{array} \\
\text { Nilai Skor }\end{array}$}} & \multirow{2}{*}{\multicolumn{2}{|c|}{$\begin{array}{c}\text { Tanah menurut kepekaanya } \\
\text { terhadap erosi }\end{array}$}} & \multirow{2}{*}{\multicolumn{2}{|c|}{$\begin{array}{c}\begin{array}{c}\text { Intensitas Hujan Harian } \\
\text { Rata - rata }\end{array} \\
\text { Nilai Skor }\end{array}$}} & \multirow{3}{*}{$\begin{array}{c}\begin{array}{c}\text { Jumlah } \\
\text { Skor }\end{array} \\
85\end{array}$} & \multirow{3}{*}{$\begin{array}{l}\text { Kawasan } \\
\text { Kawasan } \\
\text { Budidaya }\end{array}$} & \multirow{3}{*}{$\begin{array}{c}\text { Luas } \\
(\mathrm{Ha}) \\
593,58\end{array}$} \\
\hline & & & & & & & & & \\
\hline 1 & $0 \%-8 \%$ & 20 & Glei Humus & 15 & $42,06 \mathrm{~mm} /$ hari & 50 & & & \\
\hline 2 & $0 \%-8 \%$ & 20 & Kambisol & 45 & $42,06 \mathrm{~mm} /$ hari & 50 & 115 & $\begin{array}{l}\text { Kawasan } \\
\text { Budidaya }\end{array}$ & 1250,13 \\
\hline 3 & $0 \%-8 \%$ & 20 & Regosol & 75 & $42,06 \mathrm{~mm} /$ hari & 50 & 145 & $\begin{array}{c}\text { Kawasan } \\
\text { Penyangga }\end{array}$ & 402,21 \\
\hline 4 & $25 \%-40 \%$ & 80 & Glei Humus & 15 & $42,06 \mathrm{~mm} /$ hari & 50 & 145 & $\begin{array}{c}\text { Kawasan } \\
\text { Penyangga }\end{array}$ & 7,38 \\
\hline 5 & $25 \%-40 \%$ & 80 & Kambisol & 45 & $42,06 \mathrm{~mm} /$ hari & 50 & 175 & $\begin{array}{l}\text { Kawasan } \\
\text { Lindung }\end{array}$ & 3253,26 \\
\hline & & & & Total I & as (Ha) & & & & 5506,56 \\
\hline
\end{tabular}

Sumber : hasil perhitungan analisis dengan menggunakan SIG

Berdasarkan identifikasi tersebut yang dapat dilihat pada Tabel 13, maka diketahui prioritas yang pertama terdapat pada kawasan lindung yang memiliki tingkat bahaya erosi yang sangat tinggi adalah satuan lahan yang penggunaan lahannya yaitu semak belukar dan ladang (pertanian lahan kering) yang masing masing memiliki tingkat kelerengan yang curam, selanjutnya diketahui prioritas yang kedua terdapat pada kawasan penyangga yang memiliki tingkat bahaya erosi yang sangat tinggi adalah satuan lahan yang penggunaan lahan yaitu kebun campuran dengan tingkat kelerengan yang curam dan selanjutnya prioritas yang ketiga terdapat pada kawasan lindung yang memiliki tingkat bahaya erosi yang tinggi adalah satuan lahan yang penggunaan lahannya yaitu kebun campuran dengan tingkat kelerengan yang curam dan begitu juga seterusnya sampai prioritas keenam. Dari prioritas pertama sampai keenam merupakan daerah yang diperhatikan dalam praktek penanganan rehabilitas lahan dan tindakan konservasi. Hal tersebut sesuai dengan pernyataan Arsyad (2010) yang menyatakan bahwa tindakan konservasi 
berfungsi untuk mengurangi panjang lereng dan menahan air sehingga mengurangi kecepatan dan jumlah air oleh tanah, demikian erosi akan berkurang. Apabila pada satuan lahan yang nilai erosi aktual lebih kecil dibandingkan nilai erosi yang ditolerasi maka daerah tersebut diabaikan dalam penanganan tindakan konservasi. Dari uraian tersebut dengan menyusun arahan tindakan konservasi lahan yang tepat dapat mengurangi kerusakan lahan yang disebabkan oleh erosi untuk menghindari terjadinya bencana alam dan degradasi lahan yang dapat berpotensi mengalami kekritisan lahan sehingga menjaga kelestarian sumber daya tanah dan air di Sub DAS Batang Kandis.

\begin{tabular}{|c|c|c|c|c|c|c|c|c|}
\hline \multicolumn{9}{|c|}{ Tabel 13. Arahan Rehabilitas Lahan dan Konservasi Tanah di Sub DAS Batang Kandis } \\
\hline No & $\begin{array}{l}\text { Satuan } \\
\text { Lahan }\end{array}$ & $\begin{array}{c}\text { Laju } \\
\text { Erosi } \\
\text { (ton/Ha/ta } \\
\text { hun) }\end{array}$ & $\begin{array}{c}\mathrm{T} \text { maks } \\
\text { (ton/Ha/ta } \\
\text { hun) }\end{array}$ & $\begin{array}{c}\text { Perbandingan A } \\
\text { dengan } \mathrm{T}\end{array}$ & TBE & $\begin{array}{l}\text { Fungsi } \\
\text { Kawasan }\end{array}$ & Luas (Ha) & $\begin{array}{c}\text { Prioritas } \\
\text { Arahan } \\
\text { RLKT }\end{array}$ \\
\hline 1 & GCK & 309,343 & 30 & $\mathrm{~A}>\mathrm{T}$ & $\begin{array}{c}\text { Sangat } \\
\text { tinggi }\end{array}$ & $\begin{array}{c}\text { Kawasan } \\
\text { penyangga }\end{array}$ & 7,379 & Prioritas 2 \\
\hline 2 & GDK & 18,197 & 30 & $\mathrm{~A}<\mathrm{T}$ & Rendah & $\begin{array}{l}\text { Kawasan } \\
\text { budidaya }\end{array}$ & 253,622 & - \\
\hline 3 & GDP & 45,492 & 30 & $\mathrm{~A}>\mathrm{T}$ & Sedang & $\begin{array}{l}\text { Kawasan } \\
\text { budidaya }\end{array}$ & 25,526 & Prioritas 6 \\
\hline 4 & GDS & 9,098 & 30 & $\mathrm{~A}<\mathrm{T}$ & Rendah & $\begin{array}{l}\text { Kawasan } \\
\text { budidaya }\end{array}$ & 314,434 & - \\
\hline 5 & $\mathrm{KCB}$ & 1368,246 & 30 & $\mathrm{~A}>\mathrm{T}$ & $\begin{array}{c}\text { Sangat } \\
\text { tinggi }\end{array}$ & $\begin{array}{l}\text { Kawasan } \\
\text { lindung }\end{array}$ & 33,464 & Prioritas 1 \\
\hline 6 & $\mathrm{KCH}$ & 13,682 & 30 & $\mathrm{~A}<\mathrm{T}$ & Rendah & $\begin{array}{l}\text { Kawasan } \\
\text { lindung }\end{array}$ & 2298,595 & - \\
\hline 7 & $\mathrm{KCK}$ & 273,649 & 30 & $\mathrm{~A}>\mathrm{T}$ & Tinggi & $\begin{array}{l}\text { Kawasan } \\
\text { lindung }\end{array}$ & 908,746 & Prioritas 3 \\
\hline 8 & $\mathrm{KCL}$ & 957,772 & 30 & $\mathrm{~A}>\mathrm{T}$ & $\begin{array}{c}\text { Sangat } \\
\text { tinggi }\end{array}$ & $\begin{array}{l}\text { Kawasan } \\
\text { lindung }\end{array}$ & 12,449 & Prioritas 1 \\
\hline 9 & KDB & 80,485 & 30 & $\mathrm{~A}>\mathrm{T}$ & Sedang & $\begin{array}{l}\text { Kawasan } \\
\text { budidaya }\end{array}$ & 8,034 & Prioritas 6 \\
\hline 10 & $\mathrm{KDH}$ & 0,805 & 30 & $\mathrm{~A}<\mathrm{T}$ & Rendah & $\begin{array}{l}\text { Kawasan } \\
\text { budidaya }\end{array}$ & 10,141 & - \\
\hline 11 & KDK & 16,097 & 30 & $\mathrm{~A}<\mathrm{T}$ & Rendah & $\begin{array}{l}\text { Kawasan } \\
\text { budidaya }\end{array}$ & 1029,77 & - \\
\hline 12 & $\mathrm{KDP}$ & 40,243 & 30 & $\mathrm{~A}>\mathrm{T}$ & Sedang & $\begin{array}{l}\text { Kawasan } \\
\text { budidaya }\end{array}$ & 14,178 & Prioritas 6 \\
\hline 13 & KDS & 8,049 & 30 & $\mathrm{~A}<\mathrm{T}$ & Rendah & $\begin{array}{l}\text { Kawasan } \\
\text { budidaya }\end{array}$ & 188,014 & - \\
\hline 14 & RDB & 139,974 & 30 & $\mathrm{~A}>\mathrm{T}$ & Tinggi & $\begin{array}{c}\text { Kawasan } \\
\text { penyangga }\end{array}$ & 27,887 & Prioritas 4 \\
\hline 15 & RDK & 27,995 & 30 & $\mathrm{~A}<\mathrm{T}$ & Rendah & $\begin{array}{c}\text { Kawasan } \\
\text { penyangga }\end{array}$ & 23,625 & - \\
\hline 16 & RDL & 97,982 & 30 & $\mathrm{~A}>\mathrm{T}$ & Sedang & $\begin{array}{c}\text { Kawasan } \\
\text { penyangga }\end{array}$ & 202,003 & Prioritas 5 \\
\hline 17 & RDP & 69,987 & 30 & $\mathrm{~A}>\mathrm{T}$ & Sedang & $\begin{array}{c}\text { Kawasan } \\
\text { penyangga }\end{array}$ & 124,431 & Prioritas 5 \\
\hline 18 & RDS & 13,997 & 30 & $\mathrm{~A}<\mathrm{T}$ & Rendah & $\begin{array}{l}\text { Kawasan } \\
\text { penyangga }\end{array}$ & 17,3 & - \\
\hline
\end{tabular}




\section{SIMPULAN}

Berdasarkan dari hasil penelitian yang telah dilakukan di Sub DAS Batang Kandis dapat disimpulkan bahwa :

Secara umum erosi yang terjadi pada Sub DAS Batang Kandis diketahui memiliki kriteria tingkatan bahaya erosi yang sedang (TBE=2,43). Disamping itu juga diketahui kriteria tingkat bahaya erosi yang sangat tinggi hanya merupakan luasan terkecil dengan luas 53,292 Ha sekitar 0,97 \% dari keseluruhan luas Sub DAS Batang Kandis. Hal ini menunjukkan bahwa sebagian besar Sub DAS Batang Kandis memiliki nilai erosi yang masih bisa ditoleransi.

Laju erosi terbesar di Sub DAS Batang Kandis terjadi pada satuan lahan KCB dengan nilai laju erosi sebesar 1368,246 ton/ha/tahun yang termasuk dalam kriteria kelas laju erosi yang sangat berat dimana penggunaan lahannya adalah semak dan belukar pada kelerengan $25 \%$ - $40 \%$ (curam) dengan jenis tanah kambisol.

Pada satuan lahan KCB (Semak dan belukar dengan kelerengan 25\%-40\% dan jenis tanah kambisol) dan KCL (Ladang dengan kelerengan 25\%-40\% dan jenis tanah kambisol) menjadi prioritas utama berdasarkan arahan rehabilitas lahan dan konservasi tanah sebagai daerah yang perlu dilakukan tindakan konservasi.

\section{DAFTAR PUSTAKA}

Arief, A. 2001. Hutan dan Kehutanan. Kanisius, Yogyakarta.

Arsyad, S. 2010. Konservasi Tanah dan Air. IPB Inpress edisi kedua. Bogor.

Asdak, C. 2007. Hidrologi dan Pengelolaan Daerah Aliran Sungai, Gadjah Mada University Press, Yogyakarta.

Kironoto, B.A. 2003. Hydraulics of Sedimen Transport, Diktat Kuliah MPBA Universitas Gadjah Mada, Yogyakarta.
Badan Pusat Statistik. 2012. Kecamatan Koto Tangah Dalam Angka. BPS. Padang.

Baver, L.D. 1959. Soil Physics. 3rd ed. John Wiley and Sons, Inc. New York.

Budiyanto, E. 2009. Sistem Informasi Geografis dengan Arcview GIS. Penerbit Andi Yogyakarta. Yogyakarta.

Dunne, T., dan L.B Leopold. 1978. Water In Enviroment Planning. W.H Freeman and Company. New York.

Hallsworth. E. G., 1987. Anatomy, Physiology and Psychology of Erosion. John Wiley \& Sons Ltd, New York.

Hammer, W. I., 1981. Soil Conservation Consultant Report Center for Soil Research. LPT Bogor. Indonesia.

Hardiyatmo, Hary Christiady. 2006. Penanganan Tanah Longsor \& Erosi. Yogyakarta: Gadjah Mada University Press.

Hardjowigeno, 2003. Ilmu Tanah. Akademika Pessindo. Jakarta.

Kartasapoetra,G., A.G.Kartasapoetra dan M.M. Sutedjo. 2000. Teknologi Konservasi Tanah dan Air. Rineka Cipta. Jakarta. 194 halaman.

Linsley, R.K., M.A. Kohler, J.L.H. Paulus, Hermawan, 1996. Hidrologi Untuk Insinyur (Edisi Ketiga). Erlangga, Jakarta.

Nuarsa, I.W. 2005. Menganalisis Data Spasial dengan ArcViw GIS 3.3 untuk Pemula. PT Alex Media Komputindo. Jakarta.

Prahasta, E. 2002. Sistem Informasi Geografis. Penerbit Informatika Bandung.

Puntodewo, A. 2003. Sistem Informasi Geografis Untuk pengelolaan sumberdaya alam. Center for International Forestry Research. Bogor barat.

Rahim, S.E. 2003. Pengendalian Erosi Tanah Dalam Rangka Pelestarian Lingkungan Hidup. Penerbit Bumi Aksara. Jakarta.

Rusman, B. 1999. Konservasi Tanah dan Air. Fakultas Pertanian Universitas Andalas. Padang. 184 halaman.

Sarief, E. S. 1985. Konservasi Tanah dan Air. Pustaka Buana. Bandung. 
Sherbinin, 2002. Guide to Land-Use and LandCover Change (LUCC) Center for International Earth Science Information Network (CIESIN) Columbia University Palisades, NY, USA. A collaborative effort of SEDAC and the IGBP/IHDP LUCC Project.

Suratman., 2008. Permasalahan Pengelolaan Lahan Pertanian di Wilayah Tepian Danau Toba. Prosiding. Strategi Penanganan Sumberdaya Lahan untuk Mendukung Kedaulatan Pangan dan Energi. 22-23 Desember 2008. IPB, Bogor.

Suripin. 2002. Pengelolaan Sumber Daya Tanah dan Air. Andi. Yogyakarta.
Utomo, W.H. 1989. Konservasi Tanah di Indonesia. Rajawali Press. Jakarta.

Wischmeier, W.H. and Smith, D. D. 1978. Predicting Rainfall Erosion Losses A Guide to Conservation Planning. USDA Handbook No. 537. Washington DC.

Yuliadji RW, Suryono GF, Ruben A. 1994. Aplikasi SIG untuk Pemetaan Informasi Pembangunan. Di dalam Agus W, R Djamaludding, G Hendrarto, editor.Remote Sensing \& Geographic information Systems. Jakarta. 